\title{
The regulation of Christian churches: Ecclesiology, law and polity
}

\begin{tabular}{|c|c|}
\hline $\begin{array}{l}\text { Author: } \\
\text { Mark Hill } Q C^{1}\end{array}$ & \\
\hline $\begin{array}{l}\text { Affiliations: } \\
{ }^{1} \text { Centre for La } \\
\text { Cardiff Law Sc }\end{array}$ & $\begin{array}{l}N \text { and Religion, } \\
\text { hool, Wales, UK }\end{array}$ \\
\hline $\begin{array}{l}\text { 2Dickson Poon } \\
\text { King's College }\end{array}$ & $\begin{array}{l}\text { School of Law, } \\
\text { London, UK }\end{array}$ \\
\hline $\begin{array}{l}{ }^{3} \text { Department } \\
\text { History and Pc } \\
\text { Theology, Uni } \\
\text { Pretoria, Pretc } \\
\text { South Africa }\end{array}$ & $\begin{array}{l}\text { f Church } \\
\text { lity, Faculty of } \\
\text { versity of } \\
\text { oria, }\end{array}$ \\
\hline $\begin{array}{l}\text { Project leade } \\
\text { Project numb }\end{array}$ & $\begin{array}{l}\text { : G.A. Duncan } \\
\text { er: } 02618958\end{array}$ \\
\hline $\begin{array}{l}\text { Description: } \\
\text { Mark Hill is pa } \\
\text { the research p } \\
\text { of Theological } \\
\text { Africa', directe } \\
\text { Professor Gral } \\
\text { Department o } \\
\text { History and Cl } \\
\text { Faculty of The } \\
\text { University of }\end{array}$ & $\begin{array}{l}\text { rticipating in } \\
\text { roject, 'History } \\
\text { Education in } \\
\text { d by Emeritus } \\
\text { lam Duncan, } \\
\text { f Church } \\
\text { lurch Polity, } \\
\text { ology, } \\
\text { retoria. }\end{array}$ \\
\hline $\begin{array}{l}\text { Correspondin } \\
\text { Mark Hill, } \\
\text { mark.hill@ftb }\end{array}$ & $\begin{array}{l}\text { g author: } \\
\text { eu.com }\end{array}$ \\
\hline $\begin{array}{l}\text { Dates: } \\
\text { Received: } 22 \\
\text { Accepted: } 20 \\
\text { Published: } 23\end{array}$ & $\begin{array}{l}\text { eb. } 2016 \\
\text { Aug. } 2016 \\
\text { Nov. } 2016\end{array}$ \\
\hline $\begin{array}{l}\text { How to cite th } \\
\text { Hill, M., 2016, } \\
\text { of Christian ch } \\
\text { Ecclesiology, I } \\
\text { HTS Teologies } \\
\text { Theological St } \\
\text { a3382. http:// } \\
\text { org/10.4102/l }\end{array}$ & $\begin{array}{l}\text { is article: } \\
\text { 'The regulation } \\
\text { urches: } \\
\text { iw and polity', } \\
\text { Studies/ } \\
\text { udies } 72(1) \text {, } \\
\text { dx.doi. } \\
\text { ts.v72i1.3382 }\end{array}$ \\
\hline $\begin{array}{l}\text { Copyright: } \\
\text { (C) 2016. The } \\
\text { Licensee: AOS } \\
\text { is licensed un } \\
\text { Creative Comr } \\
\text { Attribution Lic }\end{array}$ & $\begin{array}{l}\text { uthors. } \\
\text { S. This work } \\
\text { ler the } \\
\text { nons } \\
\text { ense. }\end{array}$ \\
\hline Read online: & \\
\hline 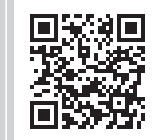 & $\begin{array}{l}\text { Scan this QR } \\
\text { code with your } \\
\text { smart phone or } \\
\text { mobile device } \\
\text { to read online. }\end{array}$ \\
\hline
\end{tabular}

This article examines the internal regulation of religious organisations in terms of their law, order or polity. It offers a systematic comparative analysis of how different Christian traditions structure and regulate themselves. The resultant legal frameworks are expressive of the institutional self-understanding of particular churches and, as such, are a form of applied ecclesiology. The paper draws upon two ongoing research studies: the Colloquium of Anglican and Roman Catholic Canon Lawyers and the Christian Law Panel of Experts, the latter having submitted a detailed submission to the World Council of Churches' Faith and Order Commission giving a legal critique of its recent document 'Towards a Common Vision'. Through a detailed methodical and comparative analysis of the various structural and regulatory formulae adopted by the different branches of the Christian family, profound similarities are discernible that are redolent with deeper theological significance. This research represents an emergent platform capable of being utilised within the ecumenical endeavour to give traction in the movement towards greater visible unity in the 21 st century.

\section{Introduction}

Through his systematic and sustained scholarship, Professor Graham Duncan has made a profound and lasting contribution to the understanding of church history and church polity. His distinguished publishing record in this field will be recognised elsewhere in this timely festschrift. However, ministerial formation and the fostering of vocations were always central to Professor Duncan's academic work: nurturing gifts of teaching and preaching in others irrespective of their age, gender or race. Training for the ministry, though led by the Spirit, has its foundations in a heightened self-understanding of the nature of the church. ${ }^{1}$ This article considers the significance of the law and polity of different Christian traditions and draws on more than a decade of work by the Colloquium of Anglican and Roman Catholic Canon Lawyers, supplemented more recently by the activities of the Panel of Experts in Christian Law. The cumulative effect of this empirical work, led by Professor Norman Doe at the Centre for Law and Religion at Cardiff University, has identified certain universal principles of Christian law that, this paper ventures, can be deployed to deepen and give greater traction to the current ecumenical endeavour (cf. Doe 2015:135-169). ${ }^{2}$

The purpose of the law for Christian communities today is much the same today as it was in the days of the early church: to regulate the functioning of the community of faith and the conduct of its component members by a combination of commands, prohibitions and permissions. Such purpose is realised in a number of ways: by God through revelation (jus divinum); by the church through its internal mechanisms of government and by the state through secular legislation (each of which being a form of jus humanum). Superficially, the law is concerned only with order and discipline (for example, Hill 2014a:15), but a closer analysis reveals that it touches upon spiritual, theological, pastoral and evangelistic concerns at the heart of the Christian faith. The law ought not to be seen as a negative and oppressive 'legalistic' instrument. Ombres (1974:296) contrasts morality, religion and law, each of which, to a greater or lesser extent, is part of an individual's life experience. 'Contrary to the perception that law is an alien concept in the relationship between God and man', Ombres indicates that:

... law, as applied ecclesiology, contributes to sustaining and expressing the freedom of the children of God. The life of the Church is structured in its institutions and organisations as is thought pastorally appropriate in her sacramental making present of Christ's life, death and resurrection. (p. 296) ${ }^{3}$

1.For consideration of the place of canon law in ministerial training, see Hill (2015:337-353).

2.The incorporation of material from Doe (2015) into this paper is done with the permission of the author

3.Attempts at an Anglican articulation of the interface between canon law and theology are to be found in Doe (1992) and Hill (1997).

Note: The author expresses his gratitude to Professor Norman Doe, Director of the Centre for Law and Religion at Cardiff Law School, for his considerable contribution to the drafting of this chapter, which builds on many years of collaborative study of comparative canon law and incorporates the findings of earlier studies set out in a series of papers authored by Professor Doe and the author separately and jointly, both published and unpublished. 
Being both utilitarian and pastoral, the law of the church seeks actively to assist members of the church following in the way of Christ and to prevent anything that may impede either the church itself or any of its members in their faith. The law in many instances provides the liturgical framework within which an expression of faith may take place. Coriden, referring particularly to the Catholic church, asserts that 'the canons also help to create and maintain the metaphors and symbols which influence the faithful subtly but strongly' (Coriden [1991] 2004:6; cf. Corecco 1991). ${ }^{4}$ It may seem incongruous that an individual professing the Christian faith, which is, by its nature, the expression of a personal spiritual belief, should fall to be governed by man-made laws and regulations. However, the integrity of any church, or indeed any secular institution, depends upon certain beliefs and behaviour being common to all its members. Proper internal governance needs greater sophistication if a church has many members and is evangelical in nature (cf. Ombres 1989). ${ }^{5}$ Further, it was Christ himself who instructed his apostles to 'bind' and to 'loose', thereby commissioning them to make provision for what was acceptable and what was not. ${ }^{6}$ Accordingly, the apostles and elders individually and collectively began a process of lawmaking for the Christian church.?

The World Council of Churches' Faith and Order Commission paper, The Church: Towards a Common Vision (2013), which took 20 years to prepare, represents 'an extraordinary ecumenical achievement' in ecclesiology (World Council of Churches 2013, Preface, viii). However, it does not explicitly consider church law, order and polity in its ecclesiology, whether as a help to ecumenism or a hindrance. The thrust of Common Vision is convergence in belief (the primary stimulus for law) and action (the primary focus of law) and its language is generally normative (the primary character of law).

The church on Earth, manifested in different institutional churches, has no single humanly created system of Christian law. ${ }^{8}$ Rather, each institutional church has its own regulatory system of law-order-polity dealing typically with ministry, governance, doctrine, worship, ritual, property and finance. Each regulatory system is the servant of that church. It facilitates and orders its life, mission and witness and binds the faithful in duties and rights for the maintenance of ecclesial communion. It translates the church's theological self-understanding into norms of conduct as applied ecclesiology.

A comparison of these norm systems contributes greatly to ecumenism. It discloses profound similarities between them and, therefore, high levels of juridical unity across the global

\footnotetext{
4. The canons call marriage a covenant rather than a contract, and a parish is described as a community of the faithful rather than a territorial part of a diocese. The effects of these characterisations, over time, are profound' (Coriden [1991] 2004:6)
}

5.For a discussion of the theology of canon law, see Ombres (1989).

6.See Mt 16:19; 18:18; 19:28; Lk 22:28-30; 10:16

7.See by way of example the rules relating to the conduct of worship prescribed by St Paul in his first epistle to the Corinthians, particularly Chapters 11 and 14 . Note also the synod of Jerusalem, probably held in AD 48 and referred to in Acts 15.

8.See the magisterial study of the subject by Doe (2012a). church families. From these similarities it is possible to induce shared juridical principles. Their existence may be factually established by observation and comparison. Churches of each tradition contribute through their own regulatory instruments to this store of principles. These principles have a living force and potential for further development and articulation. ${ }^{9}$

Common Vision, sent to the churches 'to encourage further reflection on the Church and to seek their formal responses', has 'an important role in the coming years for discerning the next steps toward visible unity'; moreover, as 'ecclesiology relates to everything the Church is and what its mission implies in and for the world', so 'agreement on ecclesiology has long been identified as the most elemental theological objective in the quest for Christian unity' (World Council of Churches 2013, Preface, Foreword, and Preface). Similarly, a key pursuit of comparative church law must be the systematic search for visible juridical unity through exposure of similarities between the regulatory systems of churches and their articulation as shared principles of law-order-polity. This juridical unity, and the common action it stimulates, may itself be understood an 'elemental aspect' of ecumenism relevant to Common Vision's principle of 'convergence'. Indeed, juridical convergence is, to borrow words from Common Vision, one of the 'aspects of ecclesial life and understanding which has been neglected or forgotten' and fits neatly its call for responses to be 'theological, practical, and pastoral'. Church law exhibits all three qualities - it is the product of theological reflection; it translates theology into practical norms of action; and its pastoral quality is evident in the principle that juridical norms are the servant of the community of the faithful seeking to enable and order life in witness to Christ (Doe 2012b:195-234). That Common Vision does not refer explicitly to, or consider, church regulatory systems and their place in ecumenism is perhaps related to the historical position of the Faith and Order Commission that 'church law' is about difference, not convergence. ${ }^{10}$ This outlook, I suggest, is somewhat misplaced: law and its ecumenical study is fertile ground for convergence. The absence of any explicit discussion in Common Vision of the role of church law impoverishes its treatment of normativity in church life. Regulatory instruments seek to order and facilitate ecclesial life. They seek to guide the faithful in their mission and witness to Christ. The value of law, polity and order can only be fully understood (and its potential realised) when it is properly perceived as facilitative and shorn of the myth that it exists not to serve the church but merely to be prohibitive.

\section{The sources, forms and purposes of church law}

For Common Vision, the church has a 'threefold mission': to proclaim the gospel, administer the sacraments and worship,

9.Note the work of the Panel of Experts (convened by the author of this article),
which met in Rome in November 2013, October 2014, September 2015 and
September 2016. For a summary of the work of the first meeting, see Hill (2014b).
10.World Council of Churches, Faith and Order Commission (1974), Document IV.8, 10.World Council of Chu
see Doe (2012a:1-2). 
and give pastoral service. The regulatory instruments of churches echo this theological standpoint. They provide that each institutional church, which may be configured at local, regional and/or international level, is an autonomous community that asserts its place in the Church of Christ and that exists to preach the gospel, to administer sacraments and worship, and to provide pastoral service (Doe 2012a). In the Protestant tradition, a Lutheran church is a national or local assembly of the faithful shaped by authoritative Reformation texts and its 'biblical foundations'; as 'part of the whole Church of Christ', its objects include to 'declare the teachings of the prophets and apostles and seek to confess in our time the faith' and to engage in 'worship and Christian service'; and it may also belong to the Lutheran World Federation. ${ }^{11}$ Similarly, in the Reformed tradition, a Reformed, Presbyterian and Congregational church (which may belong to the World Communion of Reformed Churches) asserts, typically: its place in the church universal, its doctrinal inheritance from the Reformation, its autonomy and its purposes, for example, establishing fellowships, preaching the gospel, worship, providing pastoral care and engaging in community service. ${ }^{12}$

For Common Vision, '[a]ll Christians share the conviction that Scripture is normative'. Church regulatory instruments indicate the importance of holy scripture and tradition and that these operate with other regulatory entities, which also shape church life normatively (Doe 2012a). For instance, the Roman Catholic Church has a Code of Canon Law (1983), which recognises custom and often presents canons themselves as derived from divine law. ${ }^{13}$ A Presbyterian church receives its authority from Christ, ${ }^{14}$ the 'Word of God' is the supreme 'rule of faith and life', ${ }^{15}$ and church courts and officers must 'uphold the laws of Scripture'. ${ }^{16}$

\section{The legal character of church norms}

Common Vision uses words importing juridical concepts: 'order' (par. 16); 'institutional structures and ministerial order' (par. 24); 'ecclesial order' (par. 32); 'authority' and 'power' (par. 50); 'normativity' (par 53); 'requirements' (par. 52); 'functions' (par. 52); 'obedience' (par. 51); 'cooperation and consent' (par. 51); 'good order' and 'process' (par. 54); 'duty' (par. 54); 'custom and use' (par. 55); 'jurisdiction' (par. 55); and 'obligations' (par. 64). However, Common Vision does not explain the terms as juridical in form and theological in context.

For example, Anglican laws contain 'principles, norms, standards, policies, directions, rules, precepts, prohibitions, powers, freedoms, discretions, rights, entitlements, duties,

11.The Reformation texts include the Augsburg Confession (1530) and Formula of Concord (1577).

12.Presbyterian Church of Wales (PCW), Handbook of Rules, 1.1.

13. Codex Iuris Canonici (CIC) (Code of Canon Law 1983 of the Latin Church), cc. 24, 207, 331, 1249.

14.Presbyterian Church in Ireland (PCI), Code, I.I.IV.15.

15.Presbyterian Church of Aotearoa New Zealand (PCANZ), Book of Order, 1.1(2).

16.Presbyterian Church in America (PCA), Book of Church Order, Preface, II.3; also II.7. obligations, privileges and other juridical concepts' ${ }^{\prime 17}$ For some Lutheran churches, a precondition to membership is acceptance of the constitution and bylaws, ${ }^{18}$ or classes of member 'covenant' compliance. ${ }^{19}$ In Presbyterian churches, typically, ' $[a] l 1$ members of congregations and any other person affected by any provision in the Book of Order must comply with the Book of Order ${ }^{\prime} ; 2$ and Baptists may explicitly require 'strict adherence' to 'rules and regulations'. ${ }^{21}$

\section{The faithful and lay officers}

For Common Vision, the church (universal) consists of Christ's followers (people of God), with 'obligations of responsibility', all of whom are 'interrelated'; and each institutional church has its own 'membership', for which faith in Christ is essential (World Council of Churches 2013:pars. 7, 12, 14, 16, 18, 19, 21, 23, 27). The faithful share 'communion' (koinonia), a key concept in ecumenism embracing 'participation, fellowship, [and] sharing'.

The juridical norms of churches reflect, but indicate substantially deeper agreement beyond, these Common Vision propositions about the faithful and the communion they share. Whereas 'communion' is a theological category (central to Common Vision), it also has normative-juridical aspects, particularly apposite in light of the Common Vision focus on communion as shared action and order: as spiritual communion is about relationships, so juridical systems seek to facilitate and order the communion of the faithful associated together in a church.

\section{Concepts of membership and equality}

Each church has a membership in which there is a fundamental equality but a key distinction between the laity and ordained ministers. The Roman Catholic faithful constitute the 'people of God' and each one 'participates in their own way in the priestly, prophetic and kingly office of Christ' in order 'to exercise the mission which God entrusted to the Church to fulfil in the world'; but 'by divine institution, among Christ's faithful there are ... sacred ministers [and] others called lay people'; but all enjoy 'a genuine equality of dignity and action'. ${ }^{22}$ As in Anglicanism, in which laity and clergy are 'equal in dignity before God', for Lutheran churches too, the 'people of God' embraces 'the priesthood of all believers', but there is a distinction between lay and ordained persons.

All churches comprised in this study regulate admission to membership. For example, in Anglicanism, 'membership in a church' may be based on: baptism; baptism and confirmation;

17. The Principles of Canon Law Common to the Churches of the Anglican Communion (2008) (hereafter Principles of Canon Law), Principle 4.5.

18.Lutheran Church of Great Britain (LCGB), Rules and Regulations, Congregations, 1.

19. Evangelical Lutheran Church in Canada (ELCIC), Constitution, X.3.

20.PCANZ, Book of Order, 2.2; PCA, Book of Church Order, 5.8.

21.JBU, Constitution, Art. V.

22.CIC, cc. 205, 207, 208. 
baptism, confirmation and communicant status; and/or regular attendance at worship. ${ }^{23}$ Lutheran, Reformed, Presbyterian, and Baptist churches have similar conditions. ${ }^{24}$

\section{The duties and rights of the faithful}

Churches have elaborate norms on the functions of the faithful. For instance, Orthodox must 'uphold Christian values and conduct' and 'respect' the clergy; they are 'obliged to take part in the divine services, make confession and take holy communion regularly', 'observe the canons', 'carry out deeds of faith', 'strive for religious and moral perfection' and be 'an effective witness' to the faith; their rights include participation in, for example, the parish meeting, if in 'good standing ${ }^{\prime}{ }^{25}$ Methodists have 'privileges and obligations', for example, to 'partake ... of the Lord's Supper', 'united prayer' and Christian service; and some are exercisable in private life, for example, to act as 'helpers of one another' and abstain from alcohol; their rights include entitlement to 'receive pastoral support' from ministers and if eligible to participate in governance. ${ }^{26}$

\section{Ordained ministers}

Common Vision has a detailed discussion of ordained ministry: patterns of ministry; authority and ministry; and the principle of oversight. Juridical analysis is valuable as it discloses convergence regarding principle and action.

\section{Vocation and ordination}

For Common Vision, the 'triple function of the ministry' (word, sacrament, guidance) is 'given by Christ to the Church to be carried out by some of its members for the good of all' (par. 20). Ordained ministers 'may appropriately be called priests' as 'they fulfil a particular priestly service by strengthening and building up the royal and prophetic priesthood of the faithful [in] word and sacraments', 'prayers of intercession' and 'pastoral guidance'. Common Vision encourages 'a consensus' as to whether 'the threefold ministry is part of God's will for the Church' (par. 47). Juridical analysis yields extensive consensus in principle and practice.

Suitable, qualified persons may be called to and ordained or otherwise 'set apart' for ministry, which is understood across the traditions to be of divine institution. By way of illustration, Roman Catholic law provides that ' $[b]$ y divine institution some among Christ's faithful are, through the sacrament of order, marked with an indelible character and are thus constituted sacred ministers': deacons, priests and bishops. ${ }^{27}$ Lutheran and Methodist ordained ministers engage in 'holy ministry', which is 'the gift of Christ to the church'.

23.Principles of Canon Law, Principle 27.

24.United Reformed Church (URC), Manual, A.16, Sch. A; PCW, Handbook, II.

25.Russian Orthodox Church (ROC), Statutes, XI.3; GOAA, Regulations, Art. 18.

26. Methodist Church in Ireland (MCI), Regulations, Discipline and Government, 1.03 (General Rules of our Societies, 1) and 2.04-2.08.

27.CIC, cc. 1008-1009.
Ordination itself is the process by which the vocation of individuals to serve as ministers is recognised and by which they are 'set apart' for ministry. Like the Catholic church, the Orthodox church ordains clergy by way of the laying on of hands. Similarly, in Presbyterianism, candidates must have an 'unimpeachable character', 'a deep experience of the truth of the Gospel', 'the calling of God by the Spirit, through the inward testimony of a good conscience, the manifest approbation of God's people, and the concurring judgment of a lawful court of the Church'; ' $[a]$ minister at ... ordination is set apart'.28

\section{The functions and status of ordained ministers}

For Common Vision, ministers 'assemble and build up the Body of Christ by proclaiming and teaching the Word of God, by celebrating the sacraments and by guiding ... the community in its worship, its mission and its caring ministry' (par. 19). Indeed, '[a]ll authority in the Church comes from her Lord and head, Jesus Christ', who shared his authority with the apostles and their successors (par. 48). However, the authority Christ shares with 'ministries of leadership is neither only personal, nor only delegated by the community. It is a gift of the Holy Spirit destined for the service (diakonia) of the Church'; it is exercised alongside 'the whole community, whose sense of faith (sensus fidei) contributes to the overall understanding of God's Word.

The norms of churches in this study reflect the authority, functions and lifestyle of ordained ministers as envisaged in Common Vision. For instance, an Orthodox priest is 'the spiritual father of his parish'. Roman Catholic clerics must 'seek holiness in their lives', refrain from associations inconsistent with the clerical state and lead a simple life, avoiding worldliness. ${ }^{29}$ Ministers are accountable for the exercise of their ministry to competent authority as prescribed by law (Doe 2012a:93-101).

\section{Clerical oversight}

Oversight is addressed in the laws of all churches studied here and is exercised principally by an ordained minister, usually in collaboration with others. Norms provide for numerous personal ministries of oversight at regional and/ or national level but the scope of their jurisdictions differs as between traditions - such as Catholic, Orthodox and Anglican bishops. Note also Methodist district superintendents and presidents of national conference, and regional presbyteries and moderators of general assemblies (Doe 2012a:102-113).

\section{Institutional ecclesiastical governance}

For Common Vision, Christ is the source of authority in the church. However, 'churches differ about who is competent to make final decisions'. Regulatory instruments provide 28.PCW, Handbook, 4: qualities; PCA, Book of Church Order, 16: vocation, etc. 29.CIC, cc. 276-287: holiness; continence; celibacy; study; common life; simple life; residence; dress. 
concrete evidence of the commitment of churches to these ideas and of different approaches to the location of authority identified by Common Vision. A church may have an Episcopal, Presbyterian, Congregational or other form of government as required or permitted by its conception of divine law with Christ as the head of the church universal in all its manifestations.

Across the traditions studied here, governance is exercised through a hierarchical system of international, national, regional and local institutions. The authority that an institution has at each level varies between the traditions and their doctrinal position. In the Catholic and Orthodox churches the highest authority is an international institution (the pope and/or College of Bishops, or a patriarch and Holy Synod) and authority descends to national, regional and local institutions (such as a diocesan synod or below that a parish council). In the Congregational and Baptist traditions, authority resides primarily in the local church (and is shared by laity and ministers) and ascends (for limited purposes of common action) to regional, national and international institutions. In Anglicanism, Lutheranism, Methodism and Presbyterianism, authority is located in an institution at the national level (e.g. an Anglican or Lutheran General Synod, a Methodist Conference and a Presbyterian General Assembly, all composed of both lay and ordained persons); authority then descends to regional institutions (e.g. an Anglican or Lutheran diocesan synod and a Presbyterian presbytery) and local institutions (such as a parish council or kirk session) in turn a limited authority ascends to international institutions, but these have no general legislative power over the member churches (e.g. the Anglican Communion, Lutheran World Federation and World Communion of Reformed Churches). Nevertheless, whilst they have authority appropriate to their own level, these institutions are interdependent (Doe 2012a).

\section{The regional and local church}

Common Vision asks, 'what is the appropriate relation between the various levels of life of a fully united Church and what specific ministries of leadership are needed to serve and foster those relations?' (par. 32). Churches generally organise themselves on the basis of regional and local territorial units. Catholics, Orthodox and Anglicans have dioceses (each led by a bishop). In the Protestant tradition, Lutheran churches have dioceses or synods and, within these, districts or circuits. Regional units are further composed of local units. Roman Catholic, Orthodox and Anglican dioceses are divided into parishes. Lutheran and Methodists have congregations and, sometimes, parishes, in which the church universal is present and where members gather, for example, for proclamation of the gospel and administration of the sacraments. ${ }^{30}$ In the Reformed, Presbyterian, Congregational and Baptist models, regions and districts are typically composed of circuits, congregations and local churches.

30.Lutheran Church in Great Britain (LCBG), Rules and Regulations, Definition of a Congregation, 1-2; MCGB, Constitutional Practice and Discipline, Deed of Union, 1(v)-(vi); SO 500-517.
In turn, each local unit has its own assembly for governance. A Methodist Circuit Meeting is typical: composed of the circuit superintendent, ministers and elected representatives for each local church, it is 'the principal meeting responsible for the affairs of a Circuit' and 'circuit policy'. It exercises a 'combination of spiritual leadership and administrative efficiency' and is the focal point of 'the working fellowship of the churches in the Circuit, overseeing their pastoral, teaching and evangelistic work'. In turn, the Church Council is 'the principal meeting responsible for the affairs of a Local Church' or 'Society'; composed of ministers and lay representatives elected by the annual General Church Meeting, it has 'authority and oversight over the whole area of the ministry of the church' ${ }^{31}$

\section{The relationship between local churches and regional and national institutions}

Among Christian traditions, the local church may be subject to the control or direction of regional and national institutions but nevertheless enjoy autonomy within its own sphere. For example, Catholic, Orthodox and Anglican parishes are subject to the norms and directions of diocesan institutions as well as institutions at national level. ${ }^{32}$ Similarly, Lutheran assemblies at national or regional level may exercise control over the local church and its assemblies, but each local church enjoys such autonomy as is prescribed by the general law of the church. In Presbyterianism, a (national) General Assembly may 'enact, alter or abrogate a law of the Church', and at regional level the Presbytery is 'responsible for corporate oversight of the congregations and causes assigned to it by the General Assembly'. ${ }^{33}$

\section{International governance and primacy}

Common Vision recognises that when the Church comes together to take counsel and make important decisions, there is need for someone to summon and preside over the gathering for good order and to facilitate the process of promoting, discerning and articulating consensus.

The concept of primacy dates from the early church and Common Vision records that, ' $i] \mathrm{t}$ is the duty of the ones who preside to respect the integrity of local churches, to give voice to the voiceless and to uphold unity in diversity' and that it needs 'to be exercised in communal and collegial ways' (World Council of Churches 2013:pars. 54-57).

Christian traditions provide for international oversight and leadership, with varying degrees of authority attached, in juridical norms applicable to global ecclesial communities that either constitute or are constituted by an institutional church. In the Roman Catholic church, with the pontiff, the College of Bishops exercises power over the universal church 31. MCG B, Constitutional Practice and Discipline, Deed of Union 1(iii) and So 61 . 32.CIC, cc. 447-455, 460-466; Romanian Orthodox Church (ROMOC), Statutes, Art. 19-34; Principles of Canon Law, Principles 19-20.

33.PCl, Code, pars. 104-112: General Assembly; pars. 61-79: Presbytery (which monitors the kirk session). 
and its decrees, if confirmed by the pope, are to be observed by all the faithful. ${ }^{34}$ However, at international level the institutions of the Anglican Communion (e.g. Lambeth Conference), Lutheran World Federation (Assembly, Council and Secretariat), World Methodist Council, World Communion of Reformed Churches (General Council), and Baptist World Alliance (Congress) exercise no coercive jurisdiction over their autonomous member churches.

\section{Church discipline and conflict resolution}

Common Vision records that, 'as a pilgrim community the Church contends with the reality of sin'. All churches acknowledge the fact of sin among believers and its often grievous impact and a need for Christian self-examination, penitence, conversion, reconciliation and renewal. Whatever the theological position of churches about sin within the church, the juridical instruments indicate that all the churches here recognise the capacity of the faithful to engage in wrongdoing contrary to the normative standards of the church in question. Each church has norms to address wrongdoing, resolve internal disputes and maintain church discipline.

\section{The nature and purposes of church discipline}

The churches studied here share basic ideas about the nature and purpose of ecclesiastical discipline. Typically discipline in the church is an exercise of that spiritual authority that Jesus has appointed in his church. The ends contemplated by discipline are the maintenance of the purity of the church, the spiritual benefit of the members and the honour of our Lord. All members and ministers of the church are subject to its government and discipline and are under the jurisdiction and care of the appropriate courts of the church in all matters of doctrine, worship, discipline and order in accordance with the rules and regulations from time to time applying. Discipline is for the correction of the offender and to protect the reputation and resources of the church. It is not considered to be punitive.

The instruments of churches commonly provide for the settlement of disputes by means of procedure short of formal judicial process (Hill 2011:57-77). Hierarchical recourse is used in the Catholic, Orthodox and Anglican churches. ${ }^{35}$ In Presbyterianism a congregation may refer a matter to the presbytery for advice, and several Baptist churches employ arbitration.

\section{Church courts and tribunals}

Most churches have a system of courts or tribunals for the enforcement of discipline and formal and judicial resolution of ecclesiastical disputes, at international, national, regional and/or local levels. They are established by competent 34.CIC, cc. 336-348, 360-361 and 754.

35.CIC, cC. 1732-1739. authority, administered by qualified personnel, tiered as to original and appellate jurisdiction, and exercise such authority over members as is conferred on them by law (Doe 2012a:164-171). Every effort must be made by the faithful to settle disputes amicably, lawfully and justly - recourse to church courts and tribunals is a last resort. Judicial process may be composed of informal resolution, investigation or a formal hearing as may be prescribed by law, including an appeal. Disciplinary procedures at trial must secure fair, impartial and due process on the basis of natural justice. The parties, particularly the accused, have the right to notice, to be heard, to question evidence, to silence, to an unbiased hearing and if appropriate to appeal (Hill 2014a:15).

\section{Disciplinary offences and sanctions}

Most churches have a system of ecclesiastical offences, typically apostasy, heresy, schism, 'immorality' or 'violation of the moral norms of the church', infringing doctrine, neglect of duty, acting inconsistently with ordained ministry, and conduct 'censurable by the Word of God'. Christian churches assert their inherent right to impose spiritual and other lawful censures, penalties and sanctions upon the faithful, provided a breach of discipline is established objectively. Sanctions must be lawful and just and may include admonition, rebuke, suspension, excommunication and ultimately removal from office or membership or withdrawal from spiritual privileges for the remedial or medicinal purpose of the reform of the offender and the welfare of the church. Churches may enable removal of sanctions on the basis of forgiveness leading to the restoration of the full benefits of ecclesial association (Doe 2012a:182-186).

\section{Doctrine and worship}

Common Vision proposes that proclamation of the faith is an integral action of the church, as is unity in and protection of the apostolic faith (par. 37). Interpreting the Word involves the experience of the whole people of God, insights of theologians and discernment of ordained ministers. Common Vision also recognises the need for legitimate diversity 'as an aspect of its catholicity' (par. 12). Cultural and historic factors contribute to diversity, as the gospel needs to be proclaimed in languages, symbols and images relevant to particular times and contexts. Legitimate diversity is compromised 'whenever Christians consider their own cultural expressions of the Gospel as the only authentic ones, to be imposed upon Christians of other cultures' (par. 28). Churches must be 'mutually accountable to each other' in this regard (par. 29). Christians should work 'to overcome divisions and heresies' and 'to preserve and treasure their legitimate differences of liturgy, custom and law ... [so] that they contribute to the unity and catholicity of the Church as a whole' (par. 30). Juridical systems offer models about the preservation of the inherited faith, the development of doctrine, and the authority and interpretation of scripture so as to balance loyalty to the apostolic faith and legitimate diversity of interpretation, doctrine and worship. 


\section{The sources and development of doctrine}

Churches consider doctrine as the teaching of the church on matters of faith and practice. Various norms have developed. The doctrine of a church is rooted in the revelation of God as recorded in holy scripture, summed up in the historical creeds and expounded in instruments, texts and pronouncements issued by ecclesiastical persons and institutions with lawful authority to teach. Doctrinal instruments include catechisms, articles of religion, confessions of faith and other statements of belief (Doe 2012a:188-194). The doctrines of a church may be interpreted and developed afresh, by those persons or institutions within it with competence to do so, to the extent and in the manner prescribed by the law of that church.

\section{The proclamation of the gospel}

For all the traditions, proclamation of the Word of God is a fundamental action of the church and a divine imperative incumbent on all the faithful for the evangelisation of the world. Preaching is a key function of ordained ministry but authorised lay persons may also preach. Instruction of the faithful may be by way of catechesis, Sunday school or other classes and the faithful should study Scripture. ${ }^{36}$ Each church has a right to enforce its own doctrinal standards and discipline: the faithful should believe church doctrine; ordination candidates and others may be required to subscribe or otherwise affirm their belief in or loyalty to that doctrine; and the faithful should not publicly manifest, in word or deed, a position contrary to church doctrine and those who do so may be subject to correction by means of disciplinary process. ${ }^{37}$

\section{The conduct of worship}

For all the churches studied here, the public worship of God is a fundamental action of the church and divinely instituted; it involves an encounter between the church corporately and the faithful individually with the presence of God. Each church and those persons or bodies within it competent to do so may develop liturgical texts or other forms of service for the public worship of God, provided these are consistent with the Word of God and church doctrine. The forms of service for worship may be found in a book of rites or liturgy (Catholic and Orthodox), ${ }^{38}$ a book of common prayer (e.g. Anglican), ${ }^{39}$ 'orders of worship' (Lutheran), a directory of worship (e.g. Presbyterian) and other service books lawfully authorised for use. A church must provide for public worship, and ordained ministers are responsible for its conduct in accordance with the authorised forms of service. The faithful must engage in regular attendance at divine worship, particularly on the Lord's Day, Sunday..$^{40}$ The administration

36.Cic, cc. 773-777; Principles of Canon Law, Principle 48.

37.Principles of Canon Law, Principle 53.

$38 . \mathrm{CIC}, \mathrm{cc} .2,455,826,838$ : the pope has authority over the formulation of liturgical texts.

39.Principles of Canon Law, Principles 54-55.

40.GOAA, Regulations, Art. 8. of worship is subject to supervision by designated church authorities (Doe 2012a:224-232).

\section{Rites of passage}

Common Vision identifies several ecumenical challenges with regard to ritual: who may be baptised; the presence of Christ in the Eucharist and its relation to his sacrifice on the cross; chrismation or confirmation; and those who do not affirm baptism and Eucharist but do affirm that they share in the church's sacramental life (par. 40). Whether baptism, Eucharist and other rites should be termed 'sacraments' or 'ordinances' is another challenge (World Council of Churches WCC Publications 2013:par. 44), though whichever term is used most traditions 'affirm that these events are both instrumental (in that God uses them to bring about a new reality), and expressive (of an already-existing reality)'. Churches should explore 'deeper agreement' about ecclesial life that involves these rites.

The legal evidence substantiates the differences in approaches between the traditions with regard to the classification of some rites as sacraments. The churches studied classify baptism and the Lord's Supper as sacraments (or sometimes ordinances) that have been divinely instituted. Most churches have norms on marriage and some on confession and funerals.

\section{Baptism and confirmation}

Common Vision recognises growing convergence among churches about baptism:

Through Baptism with water in the name of the Triune God, the Father, the Son and the Holy Spirit, Christians are united with Christ and with each other in the Church of every time and place.

Baptism is 'the introduction to and celebration of new life in Christ and of participation in his baptism, life, death and resurrection' and 'the water of rebirth and renewal by the Holy Spirit ... incorporating believers into the body of Christ and enabling them to share in the kingdom of God'; it 'involves confession of sin, conversion of heart, pardoning, cleansing and sanctification'; it is 'a basic bond of unity'. 'General agreement about baptism has led some who are involved in the ecumenical movement to call for the mutual recognition of baptism' (par. 41).

Juridical instruments echo these theological propositions. In Catholic law, baptism (infant or adult) is the gate to the sacraments and constitutes a rebirth as children of God configured to Christ. In baptism, Lutherans 'are incorporated into Christ', and for Presbyterians ' $[b]$ aptism is an act of the Church, and ... of God' in which 'individuals are received into the fellowship of the Church' signifying God's 'gracious purpose to save us into eternal life' ${ }^{41}$ It is administered ordinarily in public in the presence of the faithful by an ordained minister but extraordinarily in cases of necessity

41.CIC, cc. 849-878; LCGB, Rules and Regulations, Statement of Faith, 5; PCANZ, Book of Order, 6.1 . 
privately by a layperson. ${ }^{42}$ A baptism should be registered in books and cannot be repeated but, in the absence of proof of a prior valid baptism, a conditional baptism may be administered. ${ }^{43}$

\section{The Eucharist, Holy Communion or Lord's Supper}

According to Common Vision, 'a dynamic and profound relation' exists between baptism and the Eucharist: 'The communion into which the newly initiated Christian enters is brought to fuller expression and nourished in the Eucharist, which reaffirms baptismal faith and gives grace for the faithful living out of the Christian calling'. The juridical unity between the churches studied may be articulated in a number of principles. The Eucharist, Holy Communion or Lord's Supper, instituted by Christ (though churches have different doctrines about its nature), is central to ecclesial life; the faithful should participate in it regularly. It is administered by ordained persons or those otherwise lawfully deputed, normally in a public church service and exceptionally at home, such as to the sick. It is administered through the distribution of bread and wine or equivalent elements. A church by due process may exclude from admission to the sacrament those whom it judges unworthy to receive it. These norms are to be found in the Catholic, Orthodox and Anglican churches as well as the Lutheran, Methodist, Presbyterian and Baptist traditions.

\section{Marriage and divorce}

Other rites that Common Vision does not deal with include marriage. Churches have complex norms on marriage, which is defined typically as a lifelong union between one man and one woman, instituted by God for the mutual affection and support of the parties and which may be ordered to procreation. ${ }^{44}$ To be married validly in church, the parties must satisfy the conditions prescribed by church law and must have been instructed in the nature and obligations of marriage. ${ }^{45}$ The norm is marriage between church members, but this may be relaxed. Marriage is celebrated at a public service in the presence of an ordained minister and witnesses and must be registered. ${ }^{46} \mathrm{~A}$ marriage is dissolved ordinarily by the death of one of the spouses and extraordinarily when recognised as such by competent ecclesiastical authority though a minister may solemnise the marriage of a divorced person whose former spouse is still alive to the extent that this is authorised by the law of a church and conscience of the 42.CiC, cc. 849-878; Orthodox Church in America (OCIA), Guidelines for Clergy, Mystery of Baptism; Evangelical Lutheran Church of Southern Africa (ELCSA), Guidelines, 1.8.

43.CIC, cc. 849-878; ROC, Statute, XI.20; Principles of Canon Law, Principles 63, 64; United Methodist Church - United States of America (UMCNEAE), Book of Discipline, par. 226; PCl, Code, I.I.II.39.

44.CIC, c. 1055; ELCSA, Guidelines, 7.2-7.8.

45.CIC, cc. 1057-1064; OCIA, Guidelines for Clergy, Mystery of Marriage, 2: preparation; Principles of Canon Law, Principle 71

46.CIC, cc. 1108, 1115-1120; Ukrainian Orthodox Church in America (UOCIA) Instructions, Policy on Marriages, 3; Principles of Canon Law, Principles 72-73; ELCSA, Guidelines, 7.2-7.8; MCGB, Constitutional Practice and Discipline, SO 011A $\mathrm{PCl}$, Code, par. 85 . minister. Similar principles may be induced from church norms on confession and funerals (Doe 2012a:265-272).

\section{Ecumenical relations}

Common Vision invites 'leaders, theologians, and faithful of all churches to seek the unity for which Jesus prayed' (Jn 17.21) (par. 8). It notes 'a significant challenge for churches in their journey towards unity' (par. 9). Moreover, the church is called to be ever faithful to these apostolic origins (par. 22). Currently, 'some identify the Church of Christ exclusively with their own community'; some see in others 'a real but incomplete presence' of the church; some have joined 'covenant relationships'; some believe the church is 'located in all communities that present a convincing claim to be Christian'; and others maintain that 'Christ's Church is invisible and cannot be adequately identified' (par. 10).

Juridical instruments inform members and the outside world about a church's commitment to and participation in ecumenism. Some churches have well-developed ecumenical norms; others less so. Whilst divided denominationally, each church teaches that there is one holy, catholic and apostolic church, and it is a portion, member or branch of it, or else the church universal subsists in it. Ecumenism seeks the restoration of visible Christian unity - a divine imperative and its goal is full ecclesial communion. A church must promote ecumenism through dialogue and cooperation, protect the marks of the church universal and define what ecclesial communion is possible. Ecumenical activity is generally in the keeping of a central authority, but ecumenical duties may be given to the local church and to ordained ministers.

Ecumenical norms may enable interchange of ministers, the sharing of the sacraments, mixed marriages and sharing property. However, such norms are usually in the nature of exceptions to general rules that confine such facilities to the enjoyment of the faithful within the ecclesiastical tradition that created those norms. For example: 'The Church recognises the ordination of ministers of all denominations provided the ordination has been carried out by an authority representing a recognised branch of the Universal Church' ${ }^{47}$ Norms may also enable church members to share in spiritual activities such as common prayer, spiritual exercises, funerals, and in mission and social justice initiatives. The extent and terms of ecclesial communion or other relationship between churches of two or more traditions may be set out in a constitutional union, concordat, covenant or other agreement between them (Doe 2012a:304-308).

\section{Church property and finance}

In its discussion of the church and society (for which see below), Common Vision makes no mention of the temporal assets of the churches - their property and finances - and the uses of these. This too is a fertile ground to identify juridical unity among the separated churches.

47. United Free Church of Scotland (UFCS), Statement of the General Assembly, Special Constitutional Features. 


\section{Ownership of sacred property}

Churches studied here commonly assert their right to acquire, own, administer and dispose of property (which may be held at international, national, regional or local level, depending on the church in question) (Doe 2012a:310-319). Places of worship should be dedicated to the purposes of God and the activities carried out in relation to sacred property should not be inconsistent with the spiritual purposes that attach to that property. Typically, ' $[n]$ o minister shall permit anything to be done in any Church under the responsibility of such Minister which is not in accord with the laws and usages of the Church' ${ }^{48}$ Church property includes places of worship and their contents, associated buildings, church registers and records. Oversight of the administration of property vests in a competent church authority and a periodic appraisal of its condition may be the object of a lawful visitation. Provision may also be made for access to churches and for clergy residences.

\section{Control of finance}

A church has the right to make rules for the administration of its finances. The civil law on financial accountability should be complied with, and each ecclesiastical unit, through designated bodies, should prepare an annual budget for approval by its assembly. A church must provide, as to each unit, for the keeping of accounts for similar approval and ensure that these are audited annually by qualified persons to promote proper stewardship. The faithful must contribute financially to church work and church officers should encourage the faithful in this. Members are generally encouraged to engage in 'regular, weekly giving, systematic and proportionate offerings' ${ }^{49}$ A church may invest money prudently in ethical ventures consistent with its standards. Moreover, a church should insure its property against loss, remunerate ministry and make financial provision for ordained ministers who are in ill health and who retire.

\section{Church, state and society}

Each church studied has norms on the authority of the state in its own secular sphere of governance, the institutional separation of the church from the state, the requirement on the church to comply with state law, the involvement of its members in political activity, the promotion of human rights and the engagement with society in charitable, welfare, educational and other activity. These juridical facts find a direct echo in theological propositions found in Common Vision.

\section{Church and state}

Common Vision proposes that ' $[m]$ any historical, cultural and demographic factors condition the relation between Church and state [...] it is altogether appropriate for believers to play a positive role in civic life' but not to collude with secular 48. Methodist Church of New Zealand (MCNZ), Laws and Regulations, s. 2.26.1. 49.PCA, Book of Church Order, 54. authorities in sinful and unjust activities. Juridical norms echo this. The practices of the churches studied here provide that the state is instituted by God to promote and protect the temporal and common good of civil society, functions fundamentally different from those of the church. There should be a basic separation between a church and the state but a church should cooperate with the state in matters of common concern. Churches (or entities within them) may negotiate the enactment of state laws specifically devoted to them and enter agreements with the state and civil authorities to regulate matters of common concern (cf. Doe 2011). The faithful may participate in politics to the extent permitted by church law - clergy in some churches cannot hold office involving the exercise of civil power, and norms often provide that church units cannot participate in or support financially political parties or allow church property to be used for political ends. The faithful should comply with state law but disobedience by the faithful to unjust laws may be permitted. Moreover, the faithful should not resort to state courts unless all ecclesiastical process is exhausted.

\section{Human rights and religious freedom}

Common Vision sees religious freedom as one of the fundamental dimensions of human dignity and Christians should seek 'to respect that dignity and to dialogue with others to share the Christian faith' (par. 60). The exercise of religious freedom is particularly important in so far as the advance of a global secular culture provides challenges for the church, as well as meeting the challenge of a radical decline in membership and perceptions of irrelevance. 'All churches share the task of evangelisation in the face of these challenges' (par. 7).

Church law-order-polity has the potential to convert promotion of human rights and religious freedom into norms of action for the faithful. Under their regulatory texts, for each church tradition studied here, all human beings are created in the image of God, and as such all humans share an equality of dignity and fundamental human rights. In turn, the state should recognise, respect and promote basic human rights. Moreover, the church should protect and defend human rights in society for all people, and, like the church, the state and society should not discriminate against individuals on grounds of race, gender or colour. ${ }^{50}$ In addition, the state should recognise, promote and protect the religious freedom of churches corporately and of the faithful individually, as well as freedom of conscience.

\section{The church and social responsibility}

Common Vision proposes that the first attitude of God to all creation is love. So, as God intends the Church to transform the world, 'service (diakonia) belongs to the very being of the Church' (par. 58), and 'a constitutive aspect of evangelisation is the promotion of justice and peace' (par. 59); churches should discern together moral values 50.CiC, c. 204; Principles of Canon Law, Principle 26. 
uniting them (pars. 61-63). In turn, the church should help the powerless to be heard, work for a just social order and advocate peace, seeking to overcome causes of war. Christians must 'acknowledge their responsibility to defend human life and dignity' (par. 64).

Once more, church regulatory systems are valuable to translate these exhortations into action. Each church within the traditions studied here recognises for itself a responsibility to promote social justice and engage in charitable activity in wider society. As such, churches have institutions to guide, initiate and implement programmes for Christian action in society, and ordained ministers are to lead by example in the field of social justice and responsibility. Moreover, the faithful are to engage directly in the promotion of social justice and charitable work. Churches present engagement in social responsibility as a function of faith and law.

\section{Conclusion}

The routine and mundane exercise of comparing the legal frameworks of different Christian churches reveals that there are profound similarities between the basic elements of the normative regimes of governance across various ecclesiastical traditions. This is not altogether surprising: juridical unity is often based on the practice of churches in adopting a common source for shaping their laws (chiefly scripture). From these similarities, by simple scientific method, may be induced common principles of Christian law. Regulatory systems of churches shape and are shaped by ecclesiology. These systems also tell us much about convergence in action, based on common norms of conduct, as well as the commitment of churches to ecumenism. Whilst dogmas may divide churches, the widespread similarities between their norms of conduct produce regulatory convergence. This reveals that the juridical norms of the faithful, whatever their various denominational affiliations, link Christians through their encouragement of common forms of action. As laws converge, so does behaviour. These similarities between the norms of conduct of different Christian churches indicate that their faithful engage in the visible world in much the same way. Comparing church law-order-polity systems (themselves forms of applied ecclesiology) enables the articulation of principles of law-order-polity common to the churches. Laws link Christians in common action and, as Common Vision itself states, 'common action' is 'intrinsic to the life and being of the Church' (World Council of Churches 2013:par. 61). The study of church law brings a new vibrancy to ecclesiological and ecumenical scholarship. It is a rich seam and one that can be profitably mined by, among others, those whom Professor Duncan has taught and influenced during his distinguished career.

\section{Acknowledgements Competing interests}

The author declares that he has no financial or personal relationships that may have inappropriately influenced him in writing this article.

\section{References}

Corecco, E., 1991, The theology of Canon Law: A methodological question, transl. Francesco Turvasi, Duquesne University, Pittsburgh, PA.

Coriden, J., [1991] 2004, An introduction to Canon Law, Paulist Press, Mahwah, NJ.

Doe, N., 1992, 'Towards a critique of the role of theology in English ecclesiastical and Canon Law', Ecclesiastical Law Journal 2, 328. http://dx.doi.org/10.1017/S09566 $18 \times 00001526$

Doe, N., 2011, Law and religion in Europe, University Press, Oxford.

Doe, N., 2012a, Christian law: Contemporary principles, Cambridge University Press, Cambridge.

Doe, N., 2012b, 'Juridical ecumenism', Ecclesiastical Law Journal 14, 195-234. http:// dx.doi.org/10.1017/S0956618X12000038

Doe, N., 2015, 'The ecumenical value of comparative church law: Towards the category of Christian law', Ecclesiastical Law Journal 17, 135-169. http://dx.doi. org/10.1017/S0956618X15000034

Hill, M., 1997, 'Gospel and order', Ecclesiastical Law Journal 4, 659. http://dx.doi. org/10.1017/S0956618X00002805.z

Hill, M., 2011, 'Mediation: An untapped resource for the church of England?', Ecclesiastical Law Journal 13, 57-77. http://dx.doi.org/10.1017/S0956618X 10000803

Hill, M., 2014a, 'Due judicial process as a principle of Anglican canon law', in R. Torfs (ed.), The rights to due process in the Church, pp. 51-70, Peeters, Leuven.

Hill, M., 2014b, 'Christian law: An ecumenical initiative', Ecclesiastical Law Journal 16 215. http://dx.doi.org/10.1017/S0956618X1400012X

Hill, M., 2015, 'Canon law: The discipline of teaching and the teaching of the discipline', in T. Harris (ed.), Studies in canon law and common law in honor of $R \mathrm{H} \mathrm{Helmholz,}$ pp. 337-353, Robbins Collection, Berkeley, CA.

Ombres, R., 1974, 'Why then the law?', New Blackfriars 55, 296-270. http://dx.doi. org/10.1111/j.1741-2005.1974.tb06187.x

Ombres, R., 1989, 'Faith, doctrine and Roman Catholic Canon Law', Ecclesiastical Law Journal 1(4), 33. http://dx.doi.org/10.1017/\$0956618X00007237

World Council of Churches, 2013, The church: Towards a common vision, Paper 214, viewed 15 February 2016, from https://www.oikoumene.org/en/resources/ documents/commissions/faith-and-order/i-unity-the-church-and-its-mission/ the-church-towards-a-common-vision

World Council of Churches, Faith and Order Commission, 1974, 'The ecumenical movement and church law', document IV.8. 